\title{
Research Paper \\ The Effectiveness of Child-Based Mindfulness Training on the Self-Concept and Social Adaptation in Children with Internalizing Behavioral Disorders
}

\author{
Masomeh Hosenzadeh ${ }^{* 1}$, Shahla Shirani ${ }^{1}$ \\ 1. Ph.D. Student in Psychology, Najafabad Branch, Islamic Azad University, Najafabad, Iran
}

Citation: Hosenzadeh M, Shirani S. The effectiveness of child-based mindfulness training on the self-concept and social adaptation in children with internalizing behavioral disorders. Quarterly Journal of Child Mental Health. 2020; 7(1): 57-67.

http://dx.doi.org/10.29252/jcmh.7.1.6

\section{A R T I C L E I N F O}

\section{Keywords:}

Mental awareness, social adaptation, self-concept, internalized disorder

Received: 15 Oct 2017 Accepted: 17 May 2018 Available: 23 May 2020

\begin{abstract}
A B S T R A C T
Background and Purpose: Emotional behavioral disorders in children can lead to impaired social, communication, and academic performance; thus, the aim of the present study was to investigate the effectiveness of the child-based mindfulness training on self-concept and social adjustment of children with internalizing behavioral disorders.

Method: The design of this study was a pre-test-post-test semi-experimental with a control group. In order to conduct this research, a sample of 30 children with internalizing behavioral disorders in Isfahan city in the academic year of 2018-2019 city, were selected by multi-stage cluster sampling and assigned in experimental and control groups. The tools used in this study included the Children Behavioral Inventory (Achenbach and Rescorla, 2001), Children Self-Concept Questionnaire (PiersHaris, 1969), and Social Adaptation Questionnaire (Sinha and Sing, 1993). Before the intervention, both groups were tested, then the experimental group received the intervention during 10 training sessions over 2 months. The data were analyzed by analysis of covariance.

Results: The results showed that the child-based mindfulness training had a significant effect on selfconcept and social adjustment of children with internalizing behavioral disorders $(\mathrm{p}<0.001)$.

Conclusion: Based on the results of the present study, it can be said that child-based mindfulness training increases a person's psychological flexibility, feel more capable, live in the present time, and as a result feel a stronger self-concept.
\end{abstract}

\footnotetext{
* Corresponding author: Masomeh Hosenzadeh, Ph.D. Student in Psychology, Najafabad Branch, Islamic Azad University, Najafabad, Iran. E-mail addresses: Hoseinpoor48@yahoo.com
} 
اثربخشى ذهاله ئوهى آكاهى كود ككمحور بر خودينداشت و سازش يافتكى اجتماعى كود كان با اختلال هاى رفتارى دروننمود

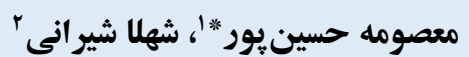

ا. دانشجوى دكتراى روانشناسى، واحد نجف آباد، دانشكاه آزاد اسلامى، نجف آباد، ايران انسئ

\begin{tabular}{|c|c|}
\hline جكيده & 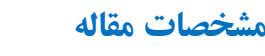 \\
\hline زمينه و هدف: بروز اختلالهاى هيجانى رفتارى در كود كان مى تواند باعث آسيب به عملكرد اجتماعى، ارتباطى، و تحصيلى منجر شود؛ & كليدوازهها: \\
\hline \multicolumn{2}{|l|}{ بدين ترتيب هدف از يزوهش حاضر بررسى اثربخشى ذهن آكاهى كودككمحور بر خودينداشت و سازشيافتكى اجتماعى كود كان داراى } \\
\hline اختلال رفتارى دروننمود است. إن. & 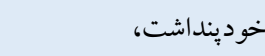 \\
\hline \multicolumn{2}{|l|}{ 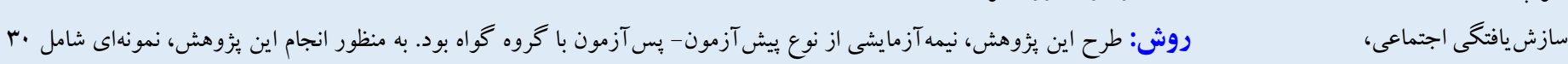 } \\
\hline نفر از كود كان داراى اختلال رفتارى دروننمود شهر اصفهان در سال تحصيلى \$ه-ههף ا، به روش نمونه گيرى خوشهاى جندمر حلهاى انتخاب، & 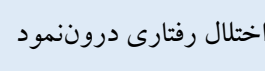 \\
\hline \multicolumn{2}{|l|}{ و در گروههاى آزمايش و گواه به صورت تصادفى جايدهى شدند. ابزارهاى استفاده شده در اين يُزوهش شامل سياهه رفتارى كودكان } \\
\hline \multicolumn{2}{|l|}{ 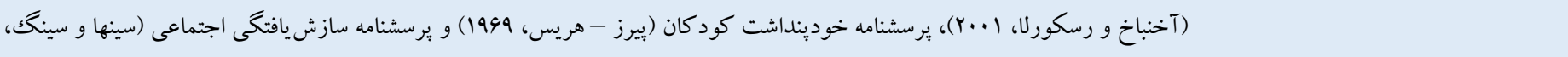 } \\
\hline \multicolumn{2}{|l|}{ 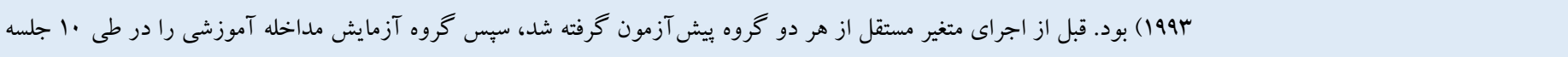 } \\
\hline \multicolumn{2}{|l|}{ آموزشى در طول r ماه دريافت كرد. دادههاى به دست آمده توسط تحليل كوواريانس تجزيه و تحليل شد. } \\
\hline \multicolumn{2}{|l|}{ يافتها: نتايج نشان داد كه آموزش ذهن آكاهى كودككمحور بر خودينداشت و سازشيافتخى اجتماعى كودكان با اختلال رفتارى } \\
\hline 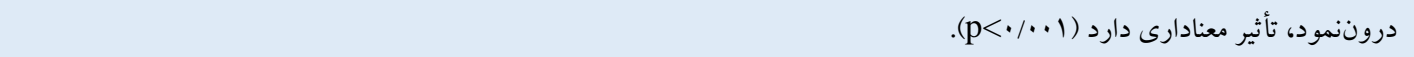 & 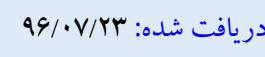 \\
\hline \multirow{2}{*}{ 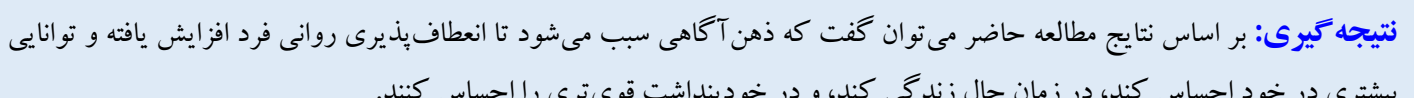 } & 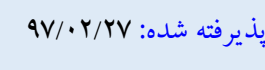 \\
\hline & 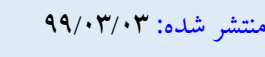 \\
\hline
\end{tabular}

* نويسنده مسئول: معصومه حسين يور، دانشجوى دكتراى روانشناسى، واحد نجف آباد، دانشكاه آزاد اسلامى، نجف آباد، ايران. راياناهة: Hoseinpoor48@yahoo.com تلفن تماس: Frrarara - Ir. 
سازش يافتكى اجتماعى با كودك را در زمان حال و آينده تهديد كرده و

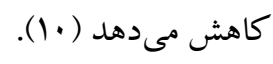

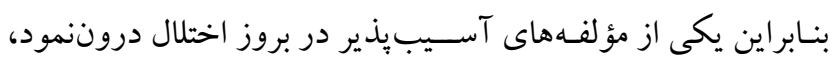

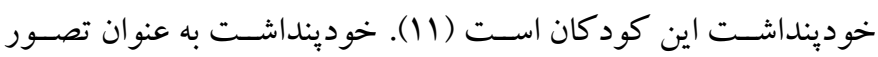

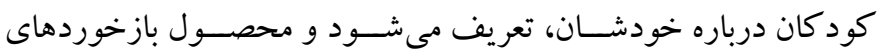

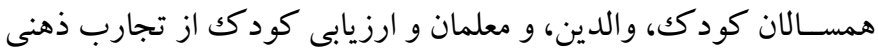
خودش اسـت (Y) (Y). خودينداشـت آموختنى است كه حاكى از آن است

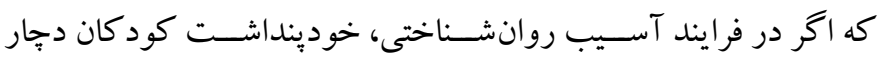

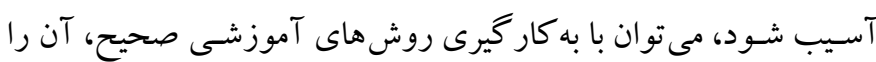

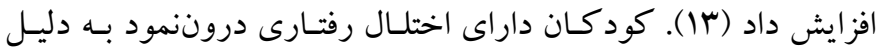

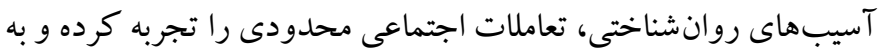
همين دليل در اغلب موارد با خودينداشت آسيب ديدهاى مو اجهاند (11).

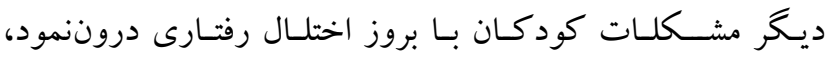

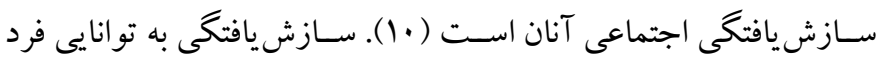

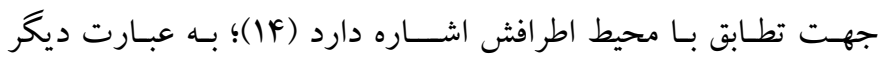

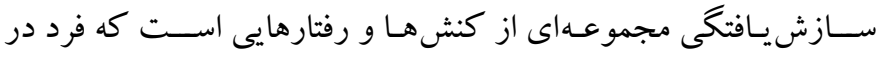
موقعيت ها و شرايط جديد به منظور ارائه ياسخهاى مناسب به محر ككهاى

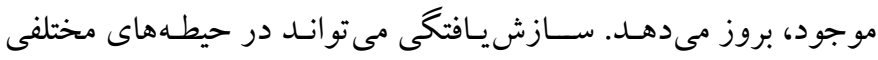
مطرح شـود و ابعاد اجتماعى، خانو ادگىى، عاطفى، شغلى و غيره را شامل

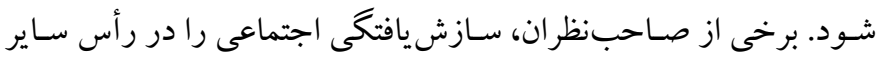

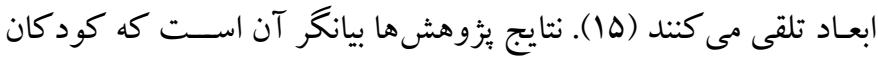

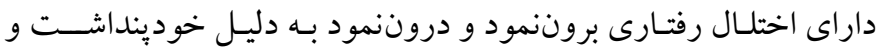

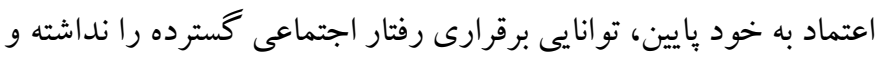

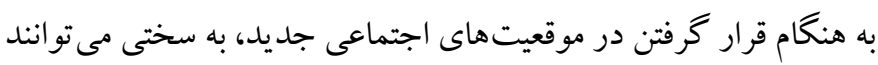
با آن سازش ييدا كرده و تكاليف اجتماعى و ارتباطى خود را انجام دهند

روش هاى درمانى مختلفى براى كود كان با آسيب هاى روانشناختى

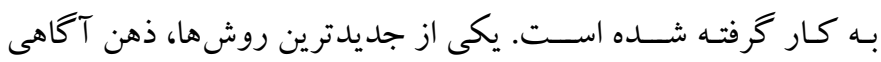

7. Obedient defensive disorder (ODD)

8. Anxiety

9. Depression

10. Self-esteem

11. Self-concept

12. Social Adjustment
مقلدمه

مشكلات رفتارى، هيجانى، روانشناختى، و عاطفى كود كان در سالهاى

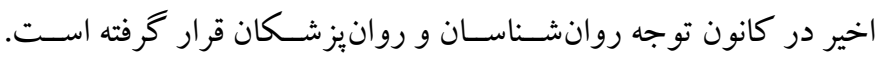

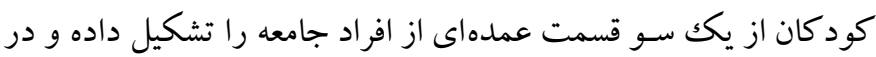

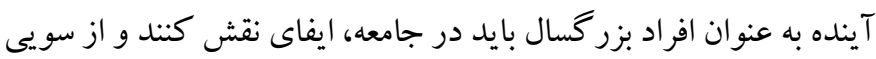

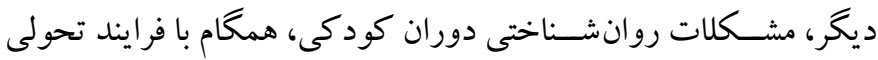

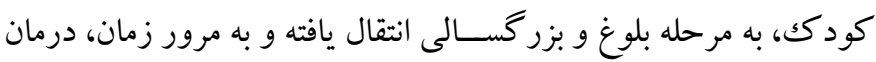

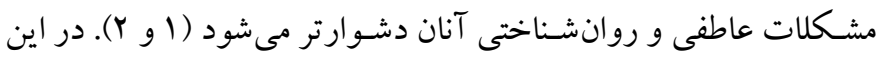

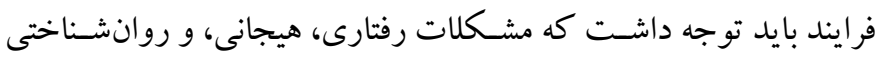

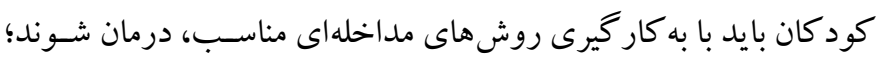

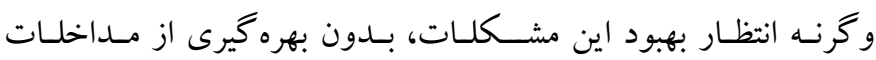

روانشناختى و آموزشى مناسب، بيهوده خو اهد بود (r).

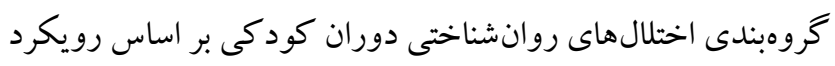

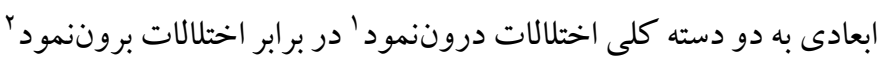

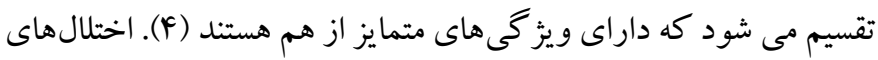

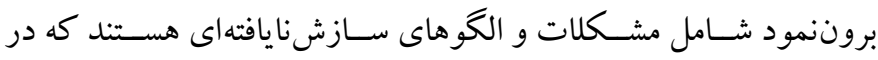

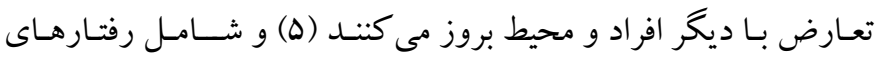

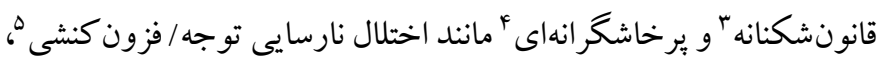

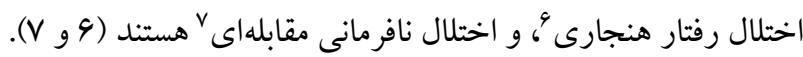

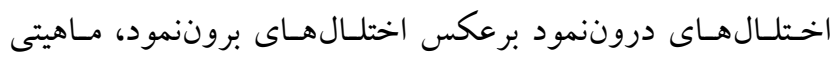

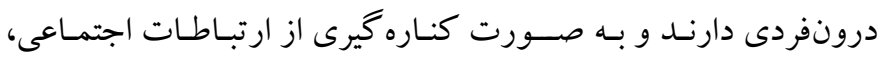

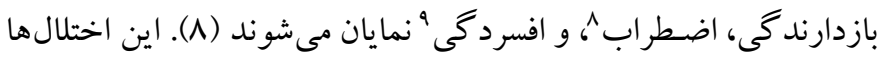

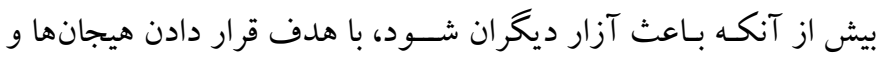
عواطف كودك، سبب آزار ديدن خود كودكك مىشوند. علاوه بر اين، اختلال هاى درون نمود با سـكوت زياد، ناميدى، و شـكايات جسـمانى

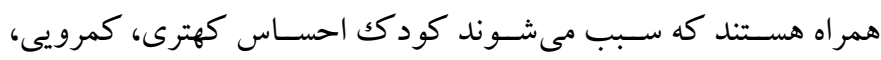

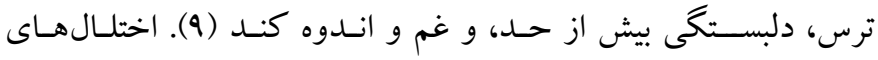

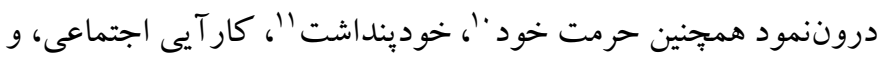

1. Externalized problems

2. Internalized problems

3. Outlaw behavior

4. Aggressive behavior

5. Attention deficit/hyperactivity disorder (ADHD)

6. Conduct disorder 
روانشـناختى و فراشـناختى باعث شـود آنان نتو انند تكاليف اجتماعى و

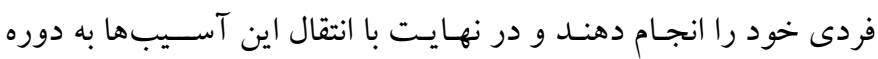

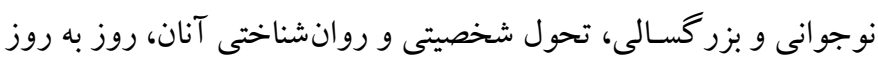
با مشكلات بيشـترى مواجه شـود. با توجه به مطالعات انجام شــده درباره

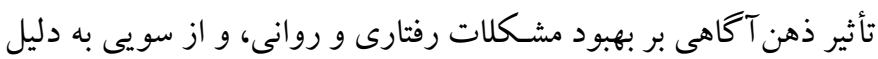

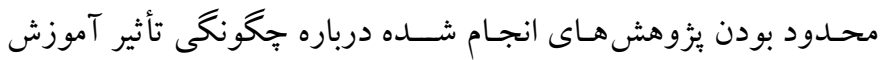

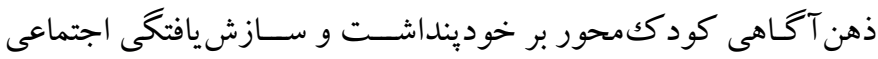

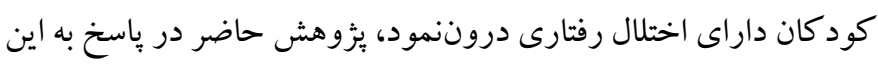

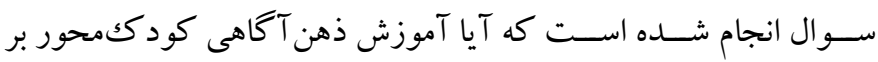

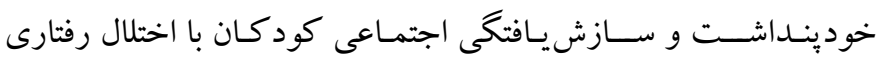

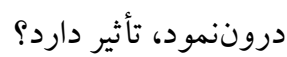

روش الف) طرح بثزوهش و شر كت كنند روش اين بثزهش از نوع نيمه آزمايشسى با طرح بيش بيش آزمون- بس بـ آزمون

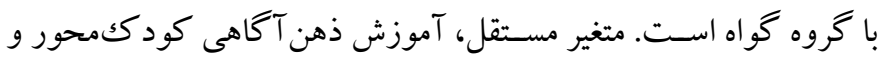

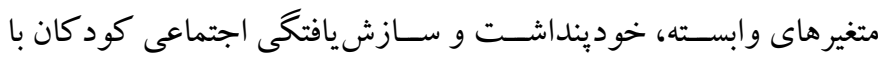

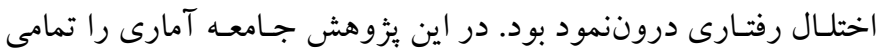

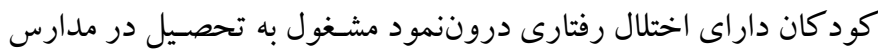

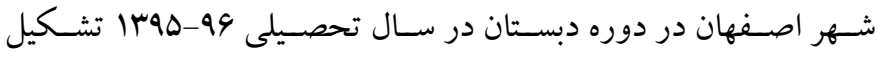

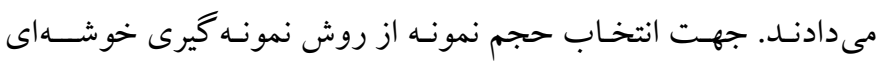

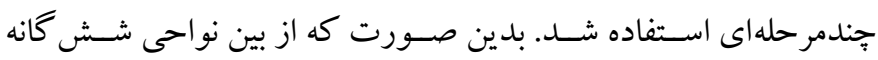

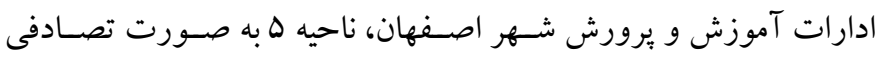

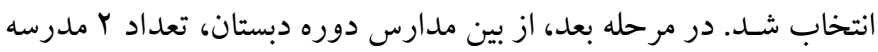

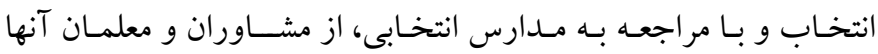

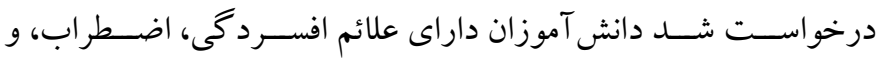

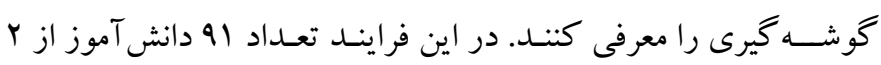

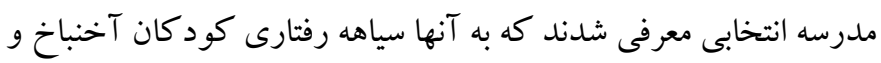
رسكورلا ارائه شـــ تا بدين وسـيله از وجود مشـكلات درون سنمود در اين

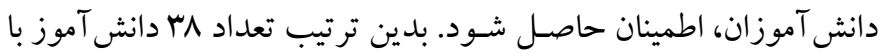

4. Anxiety

5. Post-traumatic stress disorder

6. Obsessive-compulsive disorder
كودكمتحور' اسـت كهه براى كود كان با اختلالهاى نارسـايى توجه/

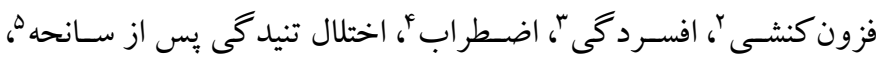

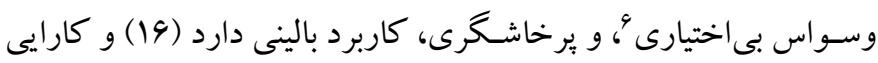

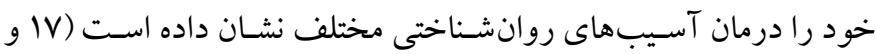

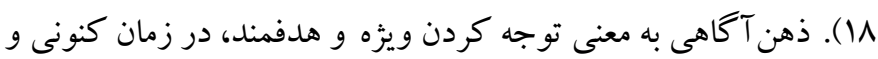

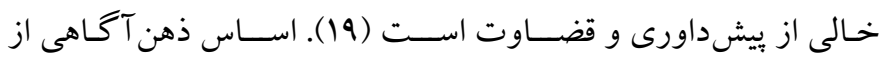
تمرين هاى مراقبه بودايسـم گر فته شـده است كه ظرفيت توجه و و آكاهى

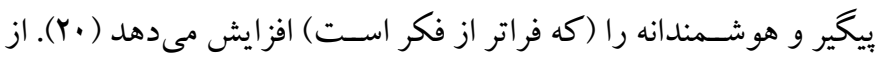

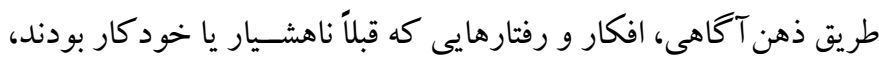
به يديدههايى قابل مشـاهده تبديل مىشوند كه در بدن يا ذهن خود فرد،

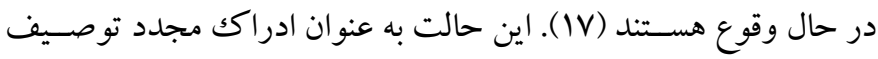
شده است؛ يعنى آن جه قبلاً موضوع بود، تبديل به شى مى شود (Y) (Y). اين

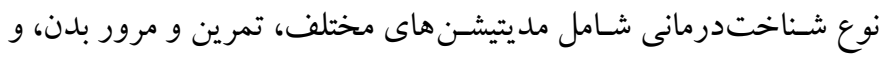

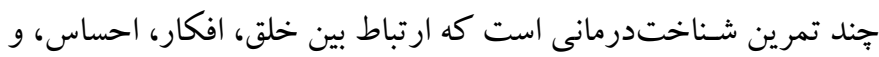
حسهـاى بــنى را نشــان مىدهد. تمامى اين تمرينها به نوعى توجه به

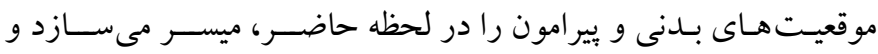

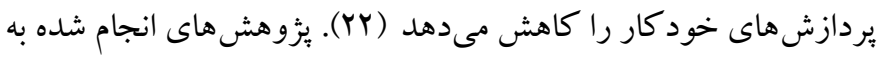

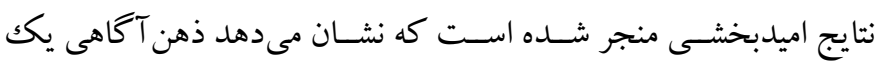

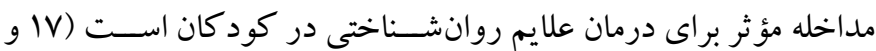

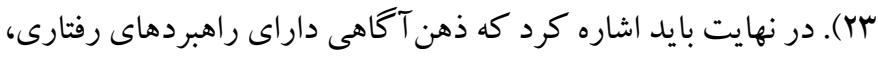
شـناختى، و فراشناختى ويزه براى متمركز كردن فرايند توجه است كه به

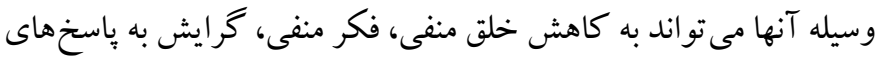

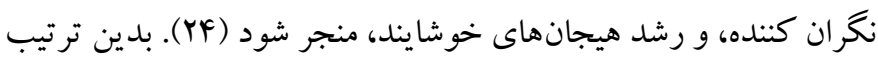

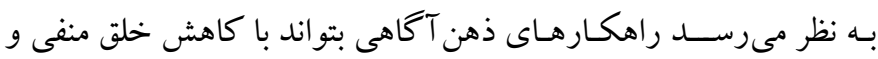

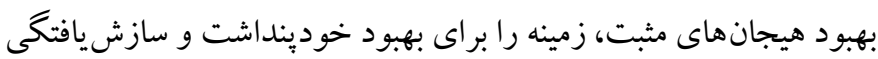
فر اهم سازد. بايد توجه داشت كه عدم توجه به مشكلات روانشناختى، رفتارى، و

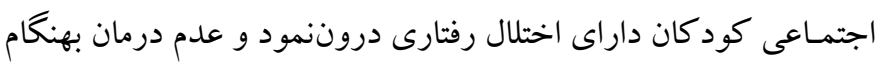

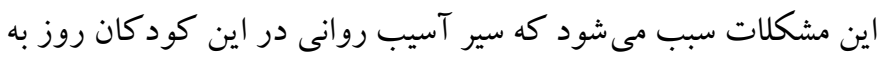

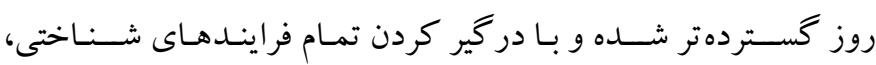

1. Child Based Mindfulness

2. Attention deficit and hyperactivity disorder

3. Depression 
دامنه نمرات مشكلات رفتارى و هيجانى از صفر تا ·YF و گستره نمرات

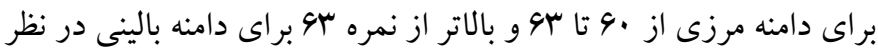

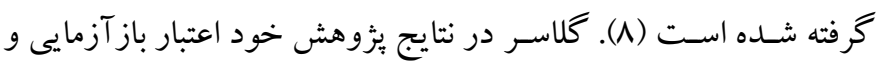

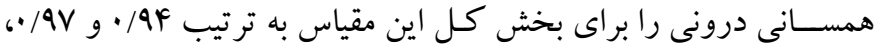

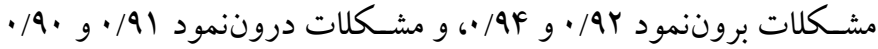

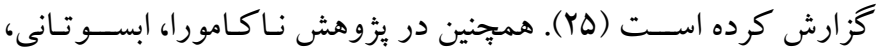

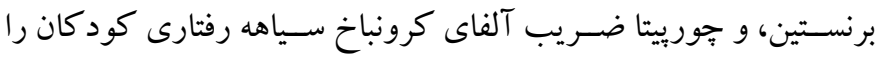

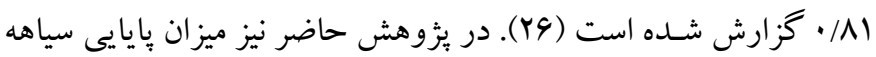
رفتارى كود كان، مشكلات بروننمود و مشكلات دروننمود با استفاده از

ضريب آلفاى كرونباخ به ترتيب M//•، צو/ • و • • به دست آمد.

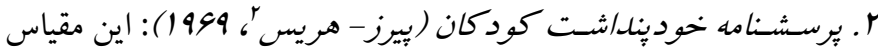

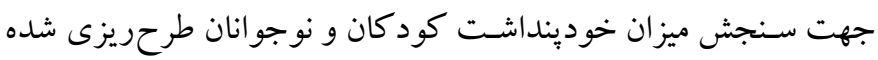
اسـت و نكخرش و احسـاس فرد نسبت به خودش را اندازه مى خيرد. تعداد

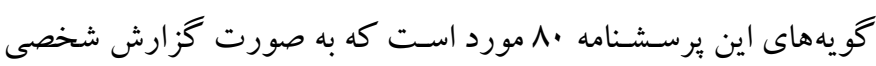
درباره اينكه كود كان و نوجوانان درباره خودشـان جه احسـاسى دارند، تدوين شدهاند. كود كان حاضر در اين بثوهش داراى دامنه سنى 9 تا سا سـال بودند كه بر اساس آن مى توانستند به سوالات يرسشنامه يُاسخ دهند. هر عبارت يرسشـنامه به صسورت دو بخشى بلى يا خير ساخته شده است. اين مقياس 9 بعد دارد: رفتار، وضسعيت مدرسـه و وضسعيت شــاختى و

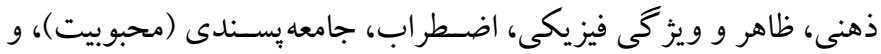
شادى. نمره بالا در اين مقياس نشاندهنده خودسنجى مثبت و ونمره وبايين،

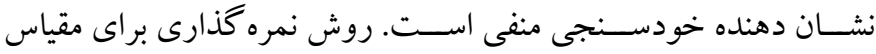

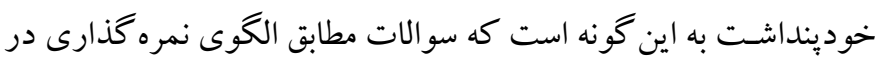
جهت خودينداشـت بالل (كافى)، نمره داده مىشوند. از مجموع نمرات 9

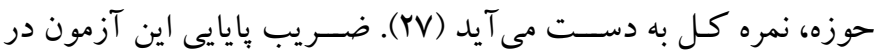

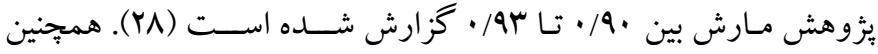

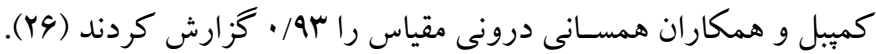

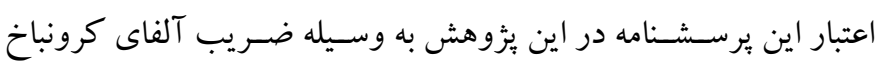

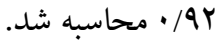

مشكلات رفتارى دروننمود تشخيص داده شدند (با استفاده از يرسشنامه سـياهه رفتارى كود كان) كه از بين آنها ·ـ نفر به تصـادف انتخاب و در درد

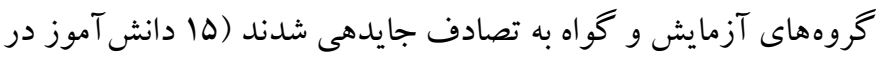

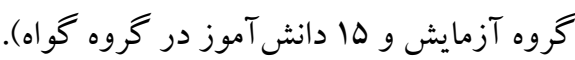

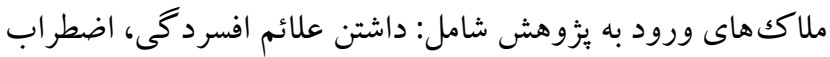

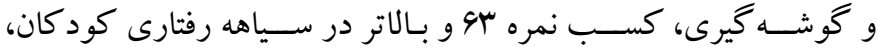
برخوردارى از سـلامت جسـمى، عملكرد انضسباطى مناسب، و دامنه سنى

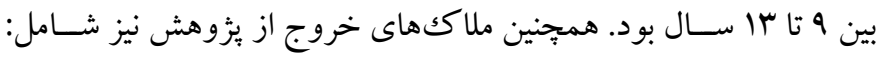

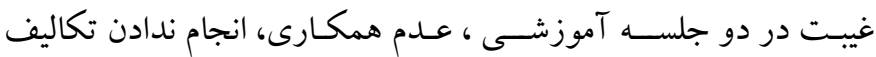
مشـخص شــده در كلاس، بروز بيمارى جسـمى حاد، و يا وقوع رخداد

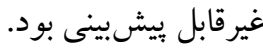
بررسى دادههاى جمعيت شناختى افر اد نمونه نشان داد كه افراد نمونه اين يزوهش داراى دامنه سـى 9 تا سا سال بودند كه در اين بين ميانخين

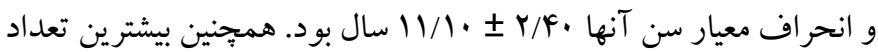
افراد نمونه مربوط به يايه تحصيلى ينجم (Fq٪) بودند.

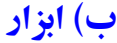
ا. سياهه رفتارى كودكان (آخنباخ و رسكورلا'، ا...r): از اين ابزار در يُزوهش حساضــر براى تشـخيص مشــكلـات رفتـارى دروننمود در

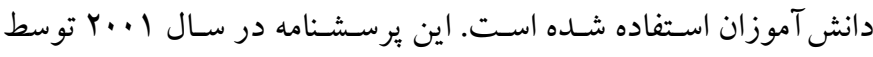
آخنباخ و رسـكورلا براى سـنجش مشكلات هيجانى و رفتارى كود كان تهيه شـده اسـت (N). سـياهه رفتارى كود كان از دو قسـمت تشكيل شده اسـت: بخش اول به بررسـى صــلاحيت كلى كودك در ســه مقياس فعاليتها، مقياس اجتماعى، و مدرسـه مى يردازد و شامل با گويه است.

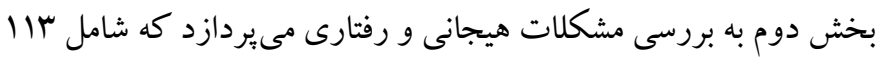

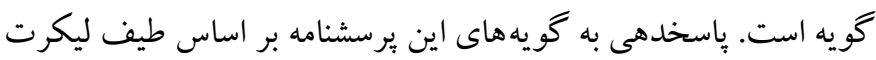

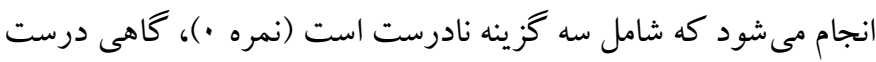

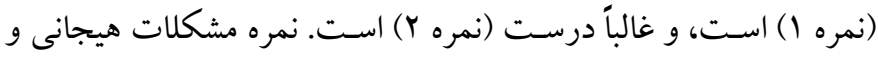
رفتـارى از طريق جمع نمرههـاى مشـكلـات رفتارى درونتمود (شــامل

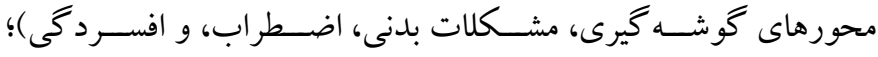

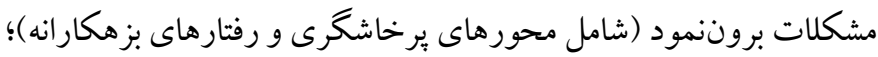
و مشـكلات توجه، مشكلات تفكر، و مشكلات اجتماعى به دست مى آيد. 
خانخانىزاده و باقرى اعتبار خردهمقياس سازش يافتكى اجتماعى با روش

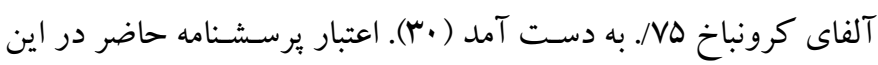

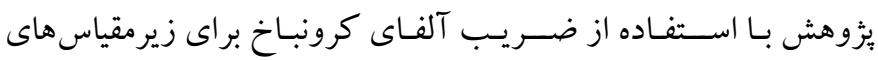

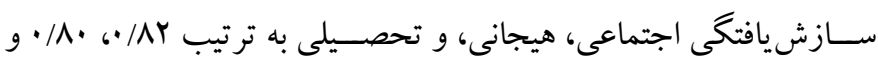
س^/ • و براى كل مقياس A9/ • محاسبه شد.

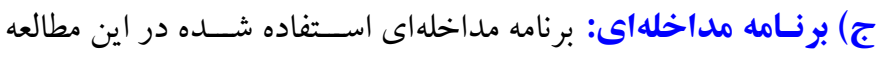

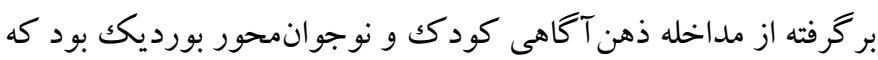

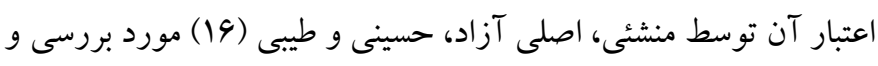

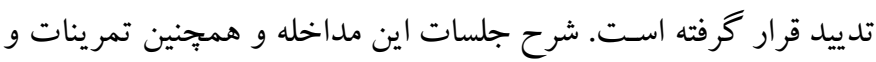
استعارههاى به كار رفته در آن، مختص سـن كودكى و نوجو انى اسـت.

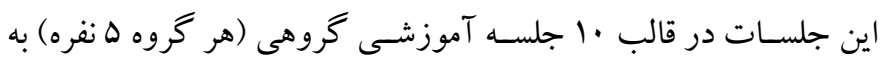

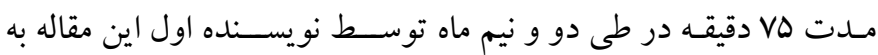
صورت هفتهاى يكك جلسه به شرح زير اجرا شد:

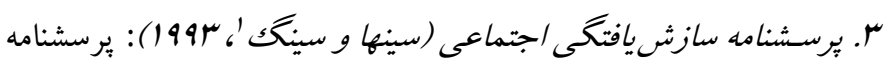

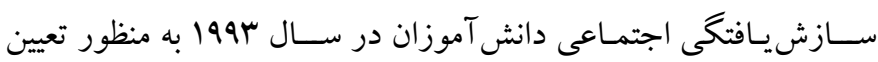

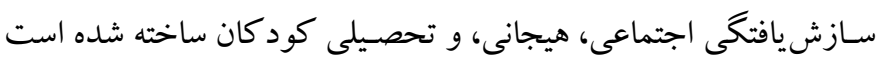

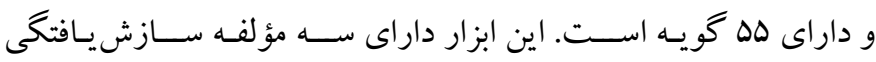

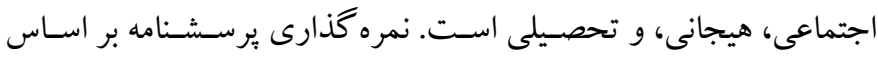

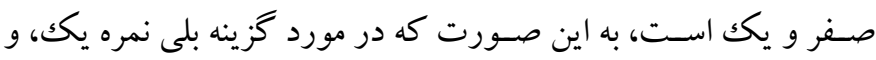

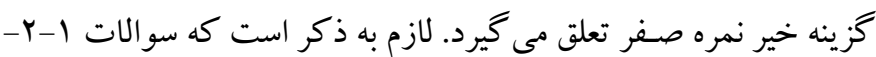
$-r Q-Y V-r q-Y \Delta-r|-r \cdot-19-19-10-| F-1 Y-1 \cdot-9-\Lambda-V-9-\Delta-r-r$ 更 معكوس است؛ بدين صورت كه به گزينه خير نمره يك،، و به كزينه بلى،

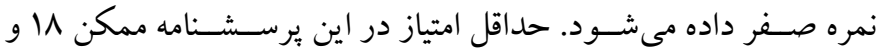

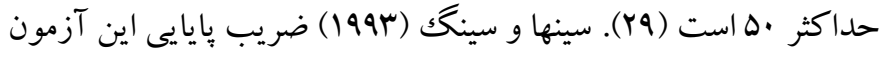
را با روش هاى دو نيمه كردن، باز آزمايى، و كودر ريجاردسون به ترتيب

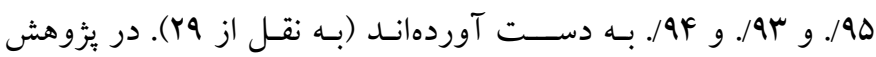

\section{جدول ا: خلاصه جلسات درمان ذهن آكاهى}

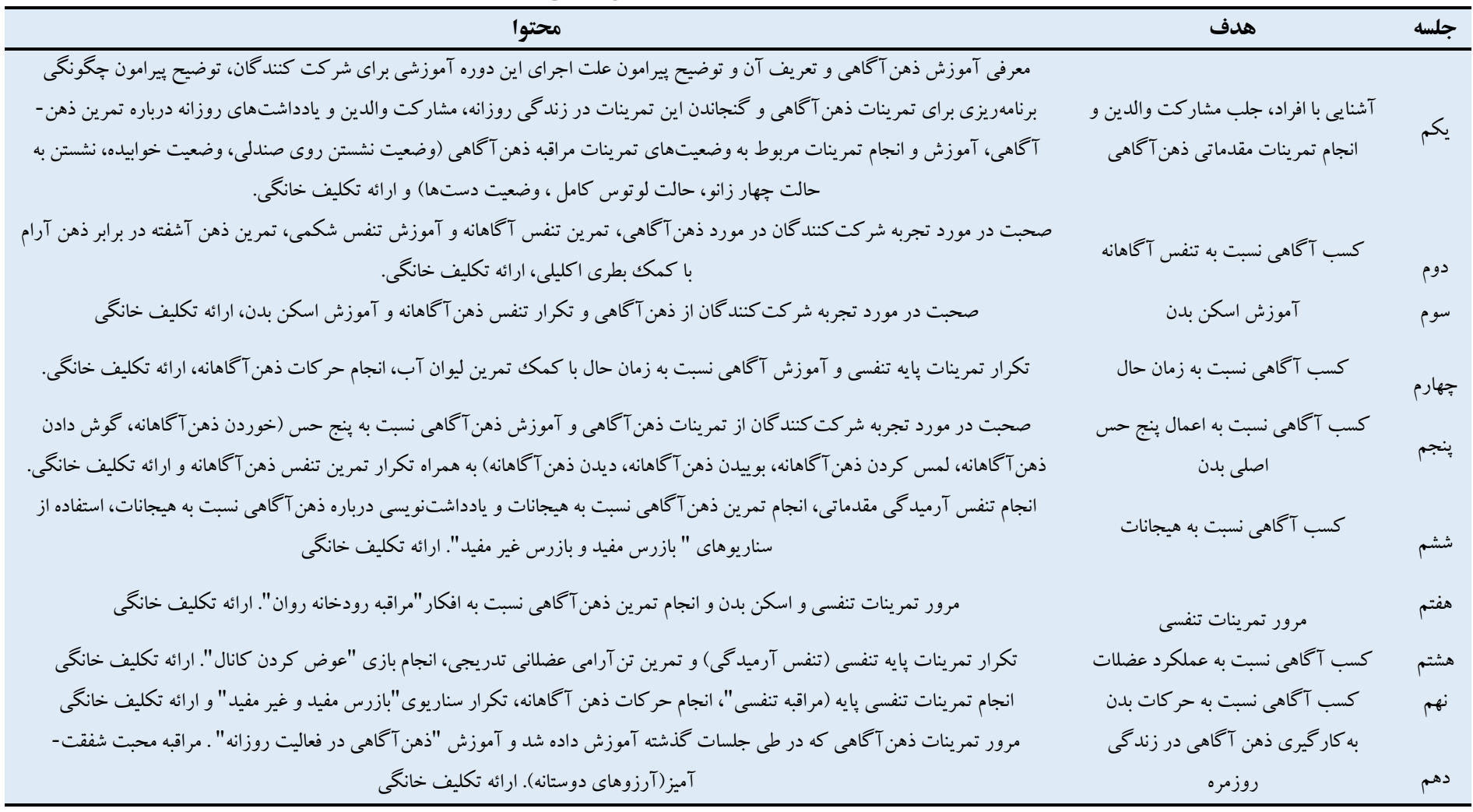


در اين يزوهش براى تحليل دادهها در سـطح توصسيفى از ميانگين و انحر اف استاندارد، و در سطح استباطى از تحليل كواريانس براى بررسى فرضيه بثوهش استفاده شد. لازم به ذكر است كه دادههاى به دست آمده در اين مطسالعه با اسـتفاده از ويرايش سب نرمافزار آمارى SPSS تحليل شدند.

\section{بافته}

يافته هاى توصيفى مؤلفه هاى خودينداشت و سازش يافتخى اجتماعى افراد نمونسه در گروههاى آزمايش و كواه در مراحل بيش آزمون و پِ بس آزمون در جدول r گزارش شده است.
د) روش اجرا: جهـت انجام اين ئزوهش، ابتدا مجوزهاى للزم از طرف اداره آموزش و برورش ناحيه ه اصـفهان كرفته شـد. ســـس با مراجعه به مدارس انتخاب شـده و انتخاب حجم نمونه با رضـايت كتبى و جايدهى آنها در كروههاى آزمايش و كو اه، يرسـشــامههاى بززوهش به صـورت گروهى بر روى افراد حاضسر در بزوهش اجرا شــد. جهت رعايت اخلاق در يزٔوهش رضـايت اوليا و دانش آموزان براى شـركت در برنامه مداخله كسـبـ شــده و از تمامى مر احل مداخله، آكاه شـــند. همبحنين به افر اد كروه كو اه، اطمينان داده شـد كه آنان نيز يس از اتمام فرايند بثزوهشـى، اين مداخلات را دريافت خواهند كرد. از ديخر ملاحظات اخلاقى مهم در اين مطالعه مى توان به محرمانه باقى ماندن اطلاعات اشاره كرد.

جدول r: نتايج آمار توصيفى در مراحل بيش و پيس آزمون

\begin{tabular}{|c|c|c|c|c|c|}
\hline \multicolumn{2}{|c|}{ هـ آزمون } & \multicolumn{2}{|c|}{ يِيش آزمون } & \multirow{2}{*}{\multicolumn{2}{|c|}{ كرووها }} \\
\hline انحراف استاندارد & ميانكين & انحراف استاندارد & ميانكين & & \\
\hline$F / 1 \Lambda$ & $r Y / 9$. & F/91 & rq/4G & سازش يافتخى اجتماعى & $T$ \\
\hline$r / 99$ & Fq/Dr & $\Delta / \cdot F$ & 4.1 .9 & خودينداشت & \\
\hline$r / 19$ & YF & $r / \cdot 1$ & $r E / M T$ & سازش يافتخى اجتماعى & $=$ \\
\hline$F / \Delta F$ & $f \cdot / f$. & $f / 10$ & rV/rg & خودينداشت & \\
\hline
\end{tabular}

همجنين بايد اشـاره كرد كه در بررسـى بيشفرض همكنى شـيب خط ركرسـيون، نتايج نشـان داد كه تعامل بيش آزمون با متغير گروهبندى در مر احل بِ آزمون در متغيرهاى خودينداشـت و سـازش يافتكى اجتماعى معنـادار نبوده اســتـ. اين بدان معناســت كه فرض همكنى شــيب خط ركرسـيون در متغيرهاى خودينداشـت و سـازش يافتخى اجتماعى برقرار بوده اســت. در جـدول ا، نتـايج تحليل كواريانس آموزش ذهن آكَاهى كود ككمحور بر خودينداشـت و سـازش يافتخى اجتماعى كود كان دار ایى اختلال رفتارى دروننمود گزارش شده است.
قبـل از ارائه نتـايج تحليل آزمون كواريانس، ييشفرض هاى آزمونهاى يارامتريكك مورد سـنجش قرار گرفت. بر اين اسـاس نتايج آزمون شاييرو ويلك نشـان داد كه بيشفرض نرمال بودن توزيع نمونهاى دادهها، برقرار اسـت(ه •/p). همجينين بيشفرض همكنى واريانس نيز توسط آزمون لوين مورد ســنجش قرار گرفت كه نتايج نشــان داد بيشفرض همخنى

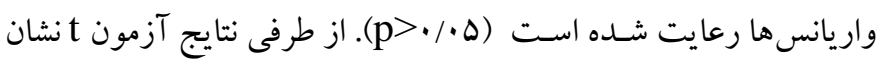
داد كه بيش آزمون گروههاى آزمايش و گرووه گو اه در متغيرهاى وابسته (خودينداشـت و سازش يافتكى اجتماعى) معنادار نبوده است (ه • • (p).

جدول "َ: نتايج تحليل كواريانس آموزش ذهن آكاهى كودكىمحور بر خودينداشت و سازش يافتكى اجتماعى كود كان با اختلال رفتارى دروننمود

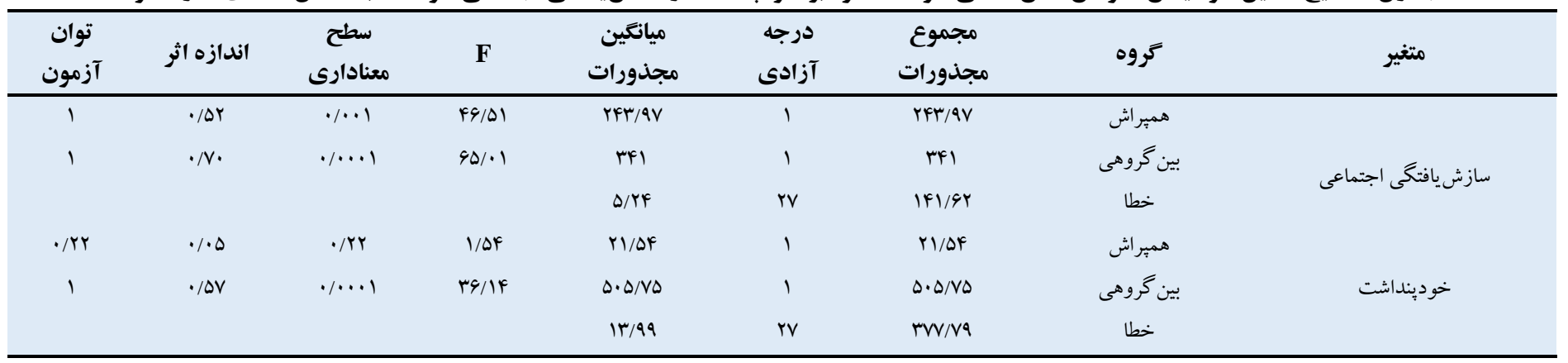


بـه منظور تبيين تـأثير حـارى مثبـت ذهن آكـاهى بر ســازش يافتكى

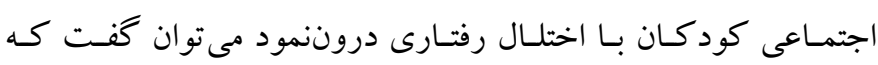

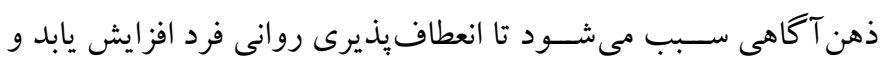
دقيقاً زمانى كه فرد به اين نتيجه دست مهى سيابد كه ديخر كارى از او ساخته

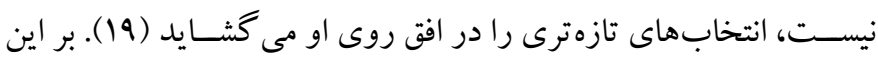

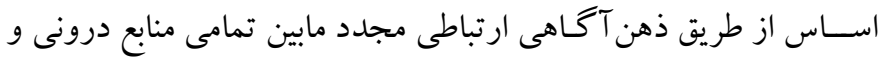

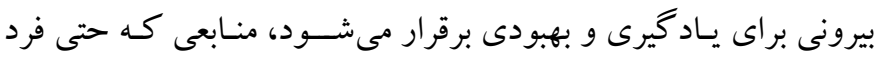

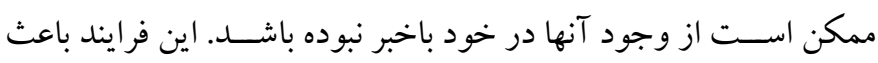

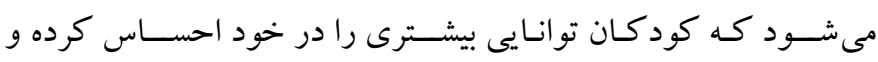

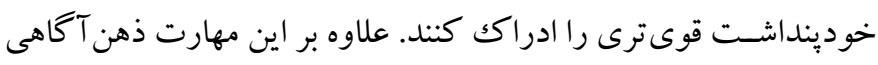

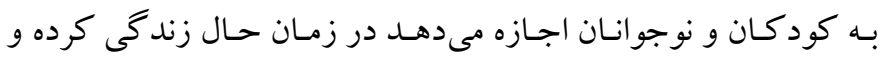

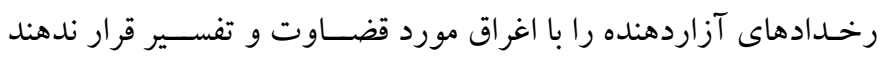

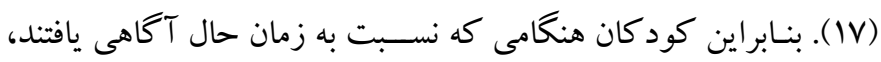

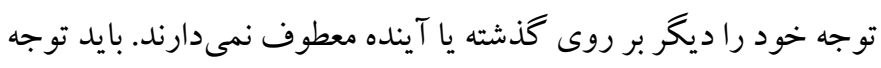

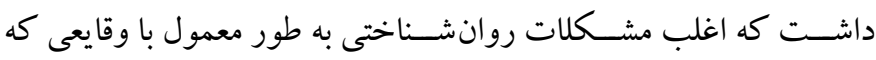

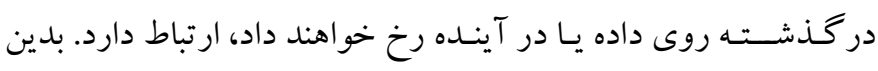

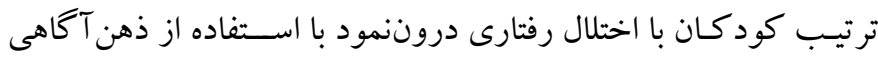

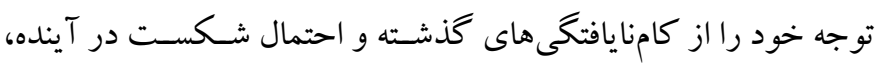

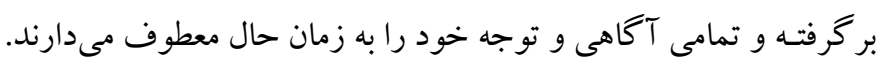

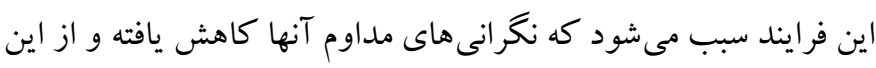

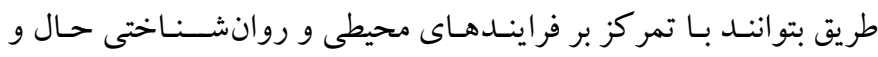

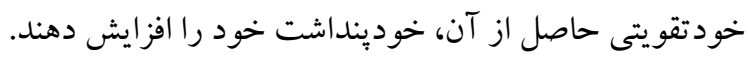

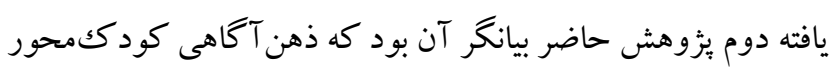

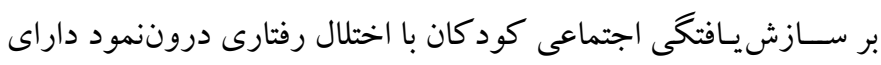

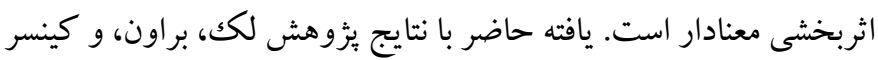

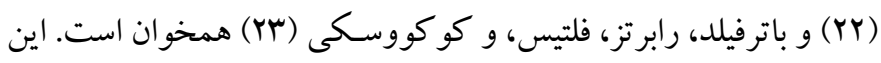

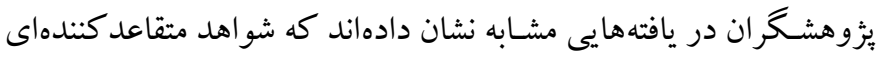

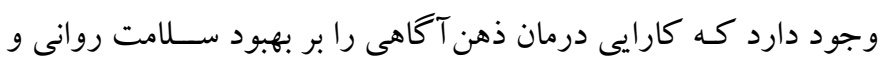

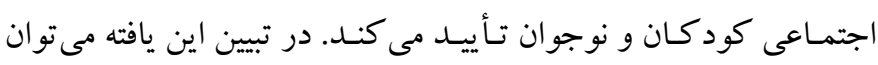

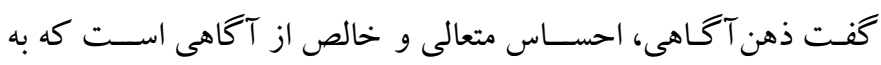

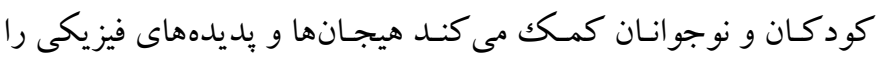
همان طور كه اتفاق مى افتند به روشسنى و وضوح مشاهده كرده و آنها را
با توجه به نتايج جدول ؟ا، آموزش متغير مستقل (آموزش ذهن آكاهى

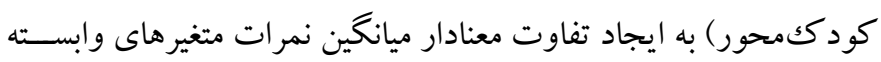
(خودينـداشــت و ســازش يـافتكى اجتمـاعى كود دكـان داراى اختلـال

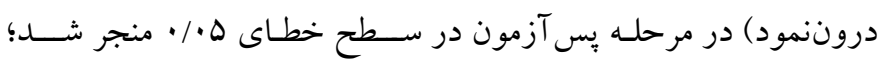

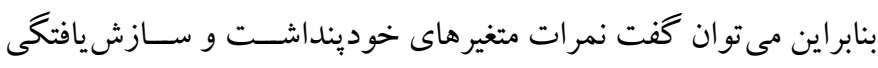

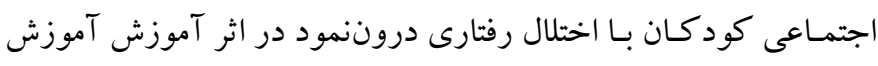
ذهن آكاهى كود ككمحور، افز ايش معنادار يافته است.

\section{جدول ع: ميانتين هاى تعديل شده متغيرهاى وابسته}

\begin{tabular}{|c|c|c|c|}
\hline خطاى استاندارد & ميانكين & كروهها & متغير \\
\hline.$/ 91$ & $F q / Y q$ & كروه آزمايش & \\
\hline.$/ 91$ & $4 \cdot 199$ & كروه گواه & خودينداشت \\
\hline .19 & $\mathrm{rl} / \mathrm{A}$. & گروه آزمايش & \\
\hline .19 & YF/Vq & گروه گواه & سازش يافتخى اجتماعى \\
\hline
\end{tabular}

جنانكه از نتايج جدول \& مشـخص اسـت نمرات ميانگين تعديل شده متغير هـاى خودينـداشـت و ســازش يافتكى اجتماعى كود كان با اختلال

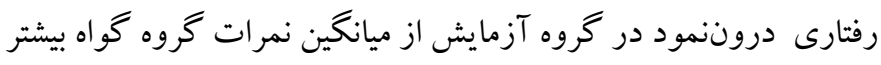

\section{بحث و نتيجه كيرى}

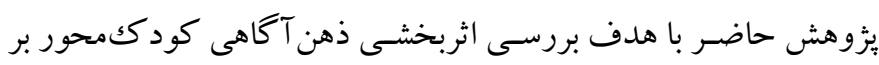

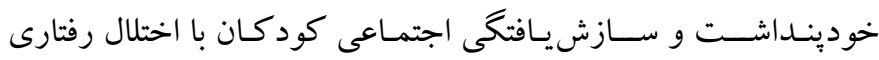
درون نمود انجام شد. يافته اول يزوهش نشان داد كه آموزش ذهن آكاهى كود ككمحور بر خودينـداشـت اين كود كان، تأثير معنادارى دارد. يافته

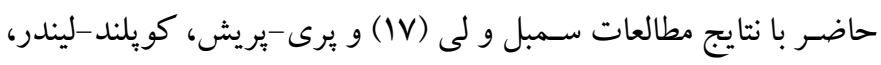
وب، و سـايبينظا همسو بود (1) همسو است. سمبل و لى در مطالعه خود

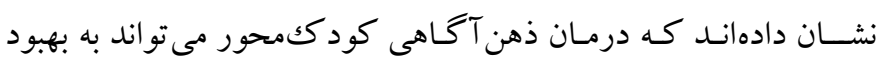

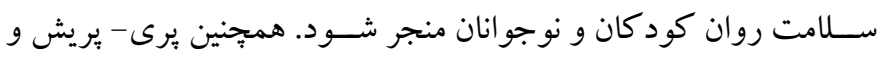

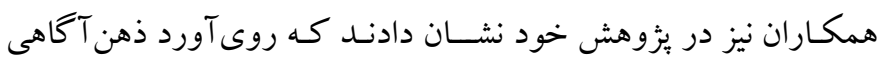

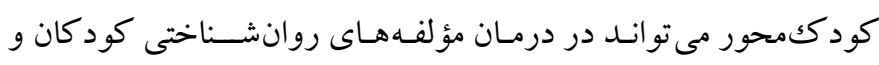

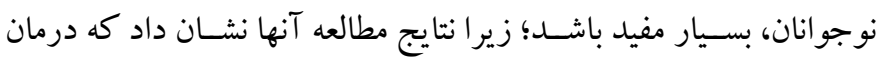

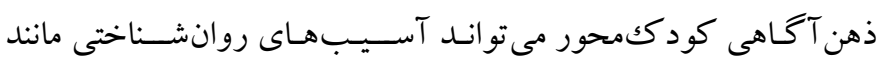
اضطراب و افسردگى را در كودكان و نوجوانان كاهش دهد (1) (1). 
دليل شرايط خاص كود كان با اختلال رفتارى دروننمود، و محدود بودن

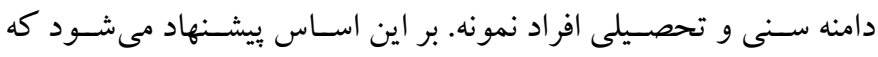

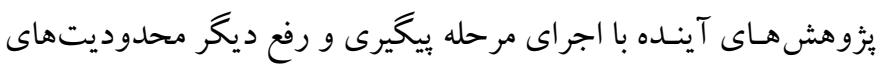

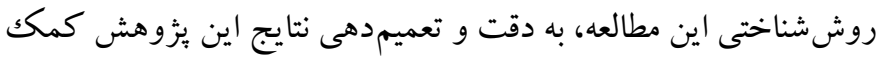

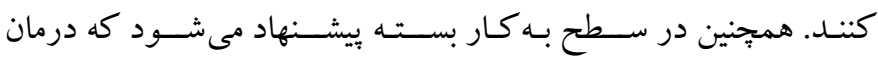

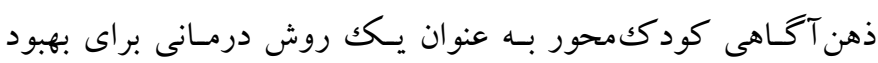

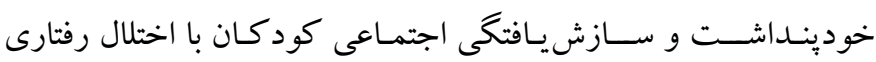
دروننمود در سـطح گروهى در مراكز آموزشسى، و در سـطح فردى درد

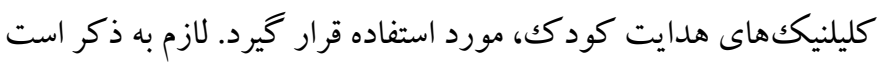

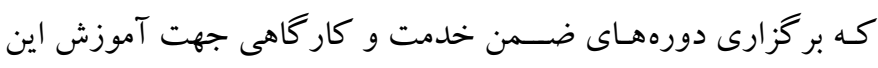
روش به مشـاوران مقاطع مختلف تحصـيلى مى تواند در رسـيدن به اين هدف، راهگشا باشد.

تشكر و قدردانى: اين مطالعه به صورت مستقل اجرا شده است. مجوز اجراى

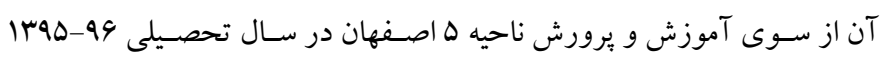
صادر و اين يزوهش تحت نظارت گروه مشاوره اين سازمان، انجام شده است.

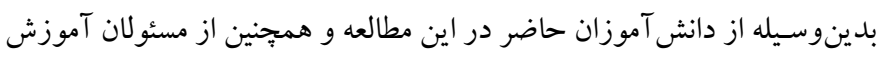

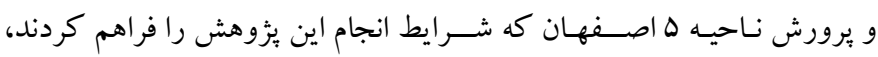
صميمانه تقدير و تشكر مى شود.

تضـاد منافع: هيج گونه تعارض منافع از سوى نويسند گان اين مطالعه گزارش نشده است.
بيذيرند (1) ). بنابر اين كود كانى كه از مشـكلات روانشـناختى ناشسى از

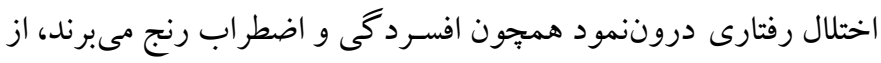

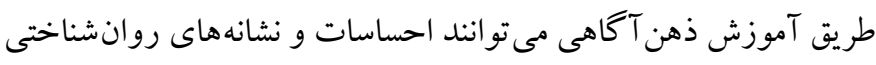

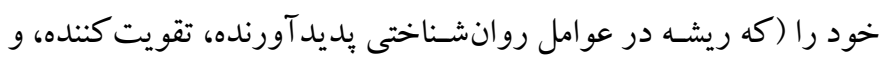

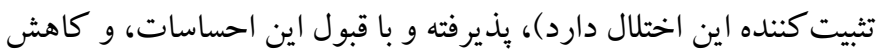

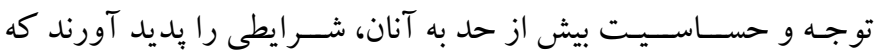

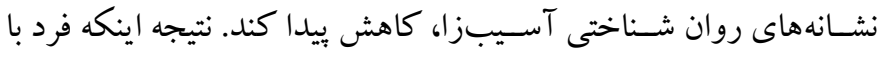
بهبود فرايندهاى روانى، تمايل بيشـترى به برقرارى روابط اجتماعى و در

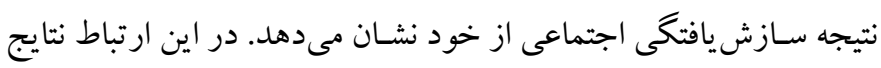

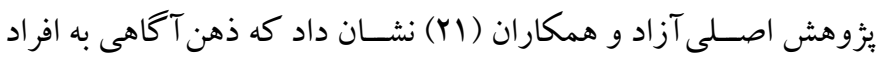

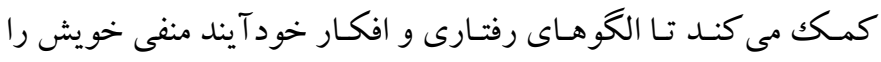

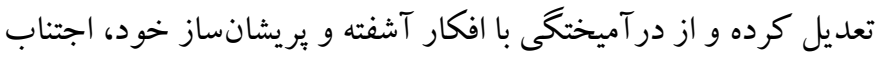

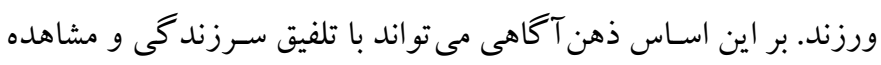

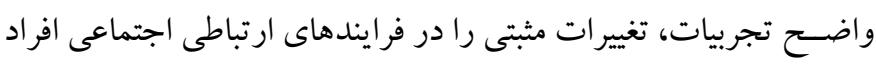

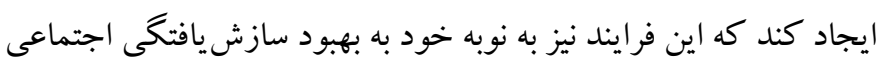
كود كان با اختلال رفتارى دروننمود منجر مى شود. اين يزوهش نيز همانند ساير يزوهش هاى علوم انسانى با محدوديت ها

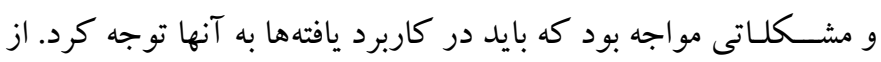

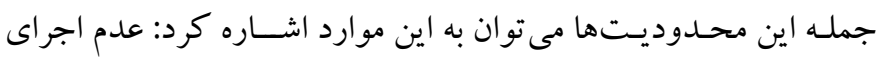
آزمون بييخيرى به دليل محدوديت زمانى، شـيوه نمونه گيرى غير تصـادفى إنى

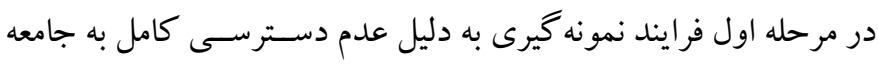

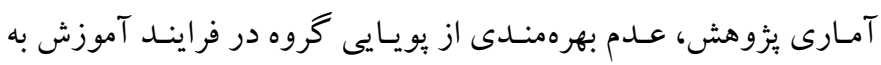




\section{References}

1. Zatto BRL, Hoglund WLG. Children's internalizing problems and teacher-child relationship quality across preschool. Early Child Res Q. 2019; 49: 28-39. [Link]

2. Alotaibi T. Combating anxiety and depression among school children and adolescents through student counseling in Saudi Arabia. Procedia Soc Behav Sci. 2015; 205: 18-29. [Link]

3. Gump BB, Dykas MJ, MacKenzie JA, Dumas AK, Hruska B, Ewart CK, et al. Background lead and mercury exposures: Psychological and behavioral problems in children. Environ Res. 2017; 158: 576582. [Link]

4. Landers AL, Bellamy JL, Danes SM, White Hawk S. Internalizing and externalizing behavioral problems of American Indian children in the child welfare system. Child Youth Serv Rev. 2017; 81: 413-421. [Link]

5. Bulten R, Brown D, Rodriguez C, Cairney J. Association of sedentary behaviour on internalizing problems in children with and without motor coordination problems. Ment Health Phys Act. 2020; 18: 100325. [Link]

6. Hoseini Yazdi A, Mashhadi A, Kimiaee SA, Asemi Z. Effectiveness of children of divorce intervention program (CODIP) on externalized and internalized problems in children of divorce. Family Psychology. 2015; 2(1): 3-14. [Persian]. [Link]

7. Rodas NV, Chavira DA, Baker BL. Emotion socialization and internalizing behavior problems in diverse youth: A bidirectional relationship across childhood. Res Dev Disabil. 2017; 62: 15-25. [Link]

8. Hamidi M, Shariat S, Aghabozorgi S, Keshavarz Mohammadi R. The effectiveness of child-based mindfulness program on impulsivity and aggression in children with externalizing disorders. Quarterly Journal of Child Mental Health. 2020; 6(4): 144-155. [Persian]. [Link]

9. Kavish N, Helton J, Vaughn MG, Boutwell BB. The association of externalizing and internalizing problems with indicators of intelligence in a sample of at-risk children. Intelligence. 2020; 80: 101448. [Link]

10. Mesman J, Bongers IL, Koot HM. Preschool developmental pathways to preadolescent internalizing and externalizing problems. J Child Psychol Psychiatry. 2001; 42(5): 679-689. [Link]

11. Nie Y-G, Li J-B, Dou K, Situ Q-M. The associations between self-consciousness and internalizing/externalizing problems among Chinese adolescents. J Adolesc. 2014; 37(5): 505-514. [Link]
12. Brown DMY, Cairney J. The synergistic effect of poor motor coordination, gender and age on selfconcept in children: A longitudinal analysis. Res Dev Disabil. 2020; 98: 103576. [Link]

13. Paulus M, Licata M, Gniewosz B, Sodian B. The impact of mother-child interaction quality and cognitive abilities on children's self-concept and selfesteem. Cogn Dev. 2018; 48: 42-51. [Link]

14. Punia S, Sangwan S. Emotional intelligence and social adaptation of school children. J Psychol. 2011; 2(2): 83-87. [Link]

15. Rodríguez Ruiz M, Holgado-Tello FP, Carrasco MÁ. The relationships between father involvement and parental acceptance on the psychological adjustment of children and adolescents: The moderating effects of clinical status. Psychiatry Res. 2017; 256: 88-95. [Link]

16. Bordick D. Mindfulness skills for the children and adolescents. Monshe'ie GR, Asli Azad A, Hoseini L, Tayebi P. (Persian translator). First edition. Isfahan: Isfahan Islamic Azad University publication (Khorasgan); 2017, pp: 369-375. [Persian].

17. Semple RJ, Lee J. Chapter 8 - Mindfulness-based cognitive therapy for children. In: Baer RA, editor. Mindfulness-based treatment approaches. Second Edition. San Diego: Academic Press; 2014, pp: 161188. [Link]

18. Perry-Parrish C, Copeland-Linder N, Webb L, Sibinga EMS. Mindfulness-based approaches for children and youth. Curr Probl Pediatr Adolesc Health Care. 2016; 46(6): 172-178. [Link]

19. Miller CJ, Brooker B. Mindfulness programming for parents and teachers of children with ADHD. Complement Ther Clin Pract. 2017; 28: 108-115. [Link]

20. Jimenez SS, Niles BL, Park CL. A mindfulness model of affect regulation and depressive symptoms: Positive emotions, mood regulation expectancies, and self-acceptance as regulatory mechanisms. Pers Individ Dif. 2010; 49(6): 645-650. [Link]

21. Asli Azad M, Manshaei G, Ghamarani A. The effect of mindfulness therapy on tolerance of uncertainty and thought-action fusion in patients with obsessivecompulsive disorder. Quarterly Journal of Child Mental Health. 2019; 6(1): 83-94. [Persian]. [Link]

22. Lack S, Brown R, Kinser PA. An integrative review of yoga and mindfulness-based approaches for children and adolescents with asthma. J Pediatr Nurs. 2020; 52: 76-81. [Link]

23. Butterfield KM, Roberts KP, Feltis LE, Kocovski NL. Chapter seven - What is the evidence in evidence- 
based mindfulness programs for children? In: Benson $\mathrm{JB}$, editor. Advances in child development and behavior. JAI; 2020, pp: 189-213. [Link]

24. Keng S-L, Smoski MJ, Robins CJ. Effects of mindfulness on psychological health: A review of empirical studies. Clin Psychol Rev. 2011; 31(6): 1041-1056. [Link]

25. Glosser R. Examination of the relationship between the child behavior checklist/ 6-18 and the social responsiveness scale parent forms using individuals with high functioning autism [Doctoral Thesis]. [Pennsylvania, USA]: Indiana University of Pennsylvania; 2011, pp: 117-120. [Link]

26. Nakamura BJ, Ebesutani C, Bernstein A, Chorpita BF. A Psychometric analysis of the child behavior checklist DSM-oriented scales. J Psychopathol Behav Assess. 2009; 31(3): 178-189. [Link]
27. Campbell JD, Trapnell PD, Heine SJ, Katz IM, Lavallee LF, Lehman DR. Self-concept clarity: Measurement, personality correlates, and cultural boundaries. J Pers Soc Psychol. 1996; 70(1): 141-156. [Link]

28. Marsh HW. Influences of internal and external frames of reference on the formation of math and English selfconcepts. J Educ Psychol. 1990; 82(1): 107-116. [Link]

29. Vieno A, Santinello M, Pastore M, Perkins DD. Social support, sense of community in school, and selfefficacy as resources during early adolescence: An integrative model. Am J Community Psychol. 2007; 39(1-2): 177-190. [Link]

30. Khan Khanizadeh H, Bagheri S. The effectiveness of verbal self-instruction on social adjustment in students with learning disabilities. Journal of Learning Disabilities. 2012; 2(1): 43-52. [Persian]. [Link] 